\title{
DEVELOPMENT OF ORGANIZATIONAL AND ECONOMIC APPROACHES TO THE ANALYSIS OF EFFICIENCY OF ACTIVITIES OF PHARMACY AS SUBJECTS OF IN- SURANCE RELATIONS IN NATIONAL HEALTH CARE
}

\author{
H. Panfilova, L. Hala
}

\begin{abstract}
Мета: розробити комплекс організаційно-економічних підходів до проведення аналізу ефективності діяльності аптечних закладів, як важливих суб'єктів страхових відносин у національній охороні здоров'я.

Матеріали і методи. У дослідженнях використовувалися дані нормативно-правової бази, щуо регулює системи обліку та звітності в аптечних закладах, а також дані спеціальної літератури. Використано історичний, аналітико-порівняльний, системний, логічний, гіпотетико-дедуктивний, математикостатистичний методи наукового пошуку та пізнання.
\end{abstract}

Результати дослідження. За результатами проведених досліджень обтрунтовані основні напрямки та чотири етапи (попередній, організаційно-адміністративний, розрахунково-результативний та управлінський) проведення аналізу ефективності діяльності аптечних закладів за умов упровадження страхових відносин. Запропоновано оновлену систему показників, яка містить 29 показників, що розподілені на два типи залежно від їх змісту, специфіки розрахунків та використання в аналізі. До першого типу (8 показників) були віднесені ті, щзо характеризують страхову рецептуру аптеки. Використання в аналізі показників другого типу (21 показник) дозволяють оцінити ефективність функціонування фінансової складової у страховій діяльності аптек. У розрахунках показників аналізу можуть бути використані натуральні, вартісні та часові облікові вимірювачі. Обгрунтовано використання в аналізі страхової діяльності аптек показників, щзо характеризують стан дебіторської заборгованості суб'єктів господарських відносин у системі фармацевтичного забезпечення населення.

Висновки. Ефективне використання даних аналізу страхової діяльності аптек дозволяє підвищувати їх соціальний статус у системі фармацевтичного забезпечення населення. Важливим напрямом перспективних досліджень є нормування показників, враховуючи специфіку діяльності аптек залежно від їх форми власності та господарювання на фармачевтичному ринку Украӥни

Ключові слова: аптека, медичне страхування, страховий рецепт, страхове відшкодування, обов'язкове медичне страхування, добровільне медичне страхування

Copyright (C) 2019, H. Panfilova, L. Hala.

This is an open access article under the CC BY license (http://creativecommons.org/licenses/by/4.0).

\section{Introduction}

The main features of the modern development of the system of pharmaceutical supply to the population is to increase the social burden on pharmacies [1, 2]. Nowadays, pharmacy establishments are regarded as important subjects performing socially-oriented tasks, despite the different socio-economic structures in the country $[3,4]$. Yes, for several years now, the issue of active participation of pharmacies in the sale of insurance products offered under voluntary medical insurance (VMI) programs has been considered in the national healthcare. In addition, the issue of reforming Ukrainian health care towards introducing a social model of mandatory health insurance (MHI) like the German model of health insurance $[5,6]$ is not removed.

According to the foreign argument, in the conditions of active functioning of health insurance (HI) pharmacy establishments perform important socioeconomic functions $[1,3,4]$. The performance of these functions is carried out using a set of indicators that allow you to evaluate the amount of work and the efficien- cy of use of resources in the process of insurance activities in the health care system. Given the lack of positive experience in implementing insurance relations at the macroeconomic level and the financial and economic instability of the functioning of public institutions, studies that provide solutions to important problems in the organization of an effective model of relations between pharmacies and other subjects of health care in the healthcare system. The active use of the results of such research will allow rational use of scarce health care resources and form a positive attitude of the population towards the introduction of insurance relations in practical medicine and pharmacy.

Problems and prospects of introduction of insurance relations in practical activity of medical and pharmaceutical institutions were investigated by domestic scientists of different scientific schools in organizational and economic direction of research in pharmacy. For example, in 2009, at the Department of Pharmaceutical Organization and Economics, National Pharmaceutical University, scientists have already proposed a system of 
indicators that allow to evaluate the effectiveness of pharmacy insurance prescription [7]. It should be noted that in the vast majority of papers, the issues of evaluating the effectiveness of the introduction of insurance relations were considered in the direction of forming a modern tariff policy, the role of pharmacy workers, primarily clinical pharmacists in the activity of pharmacies, the formation of basic and additional insurance lists of medicines and medical devices (MD) $[8,9]$. In the early 2000s, it became increasingly important to consider the historical development of $\mathrm{HI}$ in Ukraine and to build a system of reimbursement for the cost of drugs and MD consumed by different groups of patients [10]. A powerful line of research that sheds light on the issues of organization of socially effective relations between the subjects of relations in the $\mathrm{HI}$ is presented in the works of domestic economists $[11,12]$. The next area of research is presented in the works of economists, who consider the issues of financial stability and development of improving the ways of functioning of business entities subject to the introduction of insurance relations devoted to work [13, 14]. Given the increasing competition in the domestic market of HI special attention deserves work, which presents the results of the analysis of trends and features of the development of certain types of insurance activities $[15,16]$. Given the social importance of the effectiveness of the development of HI, an important area of research is the analysis of mechanisms of state regulation of insurance activity in Ukraine [17].

The development of a system of indicators of financial stability of domestic insurers is strongly influenced by the experience of countries with developed insurance markets, where such indicators have been used for decades. However, they do not reflect the peculiarities of the formation of insurance relations in the national health care, which for several decades of the development of Soviet medicine functioned under the administrative model of O.M. Semashka. The objective consequence of the lack of a consistent position of the state regarding the directions of reforming the national health care and the system of pharmaceutical provision of the population has led to the fact that with the coming to power of different political elites the issues of introducing insurance relations into practical medicine and pharmacy are considered at different angles. In 2009, against the backdrop of increasing state capacity to implement the social model of MHI in health care and stimulate the development of the VMI market in Ukraine, domestic scientists were already able to develop a system of indicators of analysis of insurance formulation, which contained 17 indicators [7]. In the absence of political will on the part of the authorities to decisively integrate insurance relations into practical health care, the results of the studies were never used in the organization of pharmacies. Since then, historical changes have taken place in Ukraine, both in the priorities of development of the whole society and the state, as well as of national health care and the system of pharmaceutical provision of the population. At the present stage of development of the pharmaceutical market, there are qualitative changes that reflect the processes of increasing the social burden on pharmacy establishments. In addition, pharmacies have become more and more active each year in the imple- mentation of government programs and projects aimed at increasing the availability of pharmaceutical assistance to the public through the introduction of e-Health. Therefore, there was a need to review organizational and economic approaches to assess the effectiveness of pharmacies, as important subjects of insurance relations in the health care system. In addition, it is necessary to update the composition, content and procedure of calculations of the main indicators, the practical use of which will allow to organize the activity of pharmacies at a new level that meets the main goals of the National Medicinal Policy (availability, quality and rationality of use of medicines).

The purpose of the study is to develop organizational and economic approaches to analyze the effectiveness of pharmacies in the conditions of introduction of insurance relations in health care and the system of pharmaceutical supply of the population of Ukraine.

\section{Planning (methodology) of the research}

In the first phase of our research, it was necessary to outline the research objects that would meet the main purpose of the research and the specifics of the system being developed. First of all, these indicators, from one point of view, should reflect the features of insurance activities with HI, and on the other - the organization of accounting and reporting in pharmacies. According to the systematization of the specialized literature, the results of previously conducted research in the indicated direction and the relevant legal framework we selected forms, methods, organizational and economic approaches and methods of accounting and reporting system management in pharmacies of different forms of ownership, including the conditions of implementation of insurance relations in health care.

To achieve the aim of the study, the following design of theoretical studies was developed and elaborated, which included the following steps:

- to analyze the data of the relevant legal framework and specialized literature, which presents the results of research on the selected topic;

- to identify the main directions of development of organizational and economic approaches to the analysis of the effectiveness of pharmacy establishments under conditions of introduction of insurance relations in the health care system;

- to develop a modern system of indicators that characterizes the effectiveness of insurance activities of pharmacies and analyze their content;

- to systematize these indicators by groups according to the peculiarities of their use in the practice of pharmacy institutions providing public health insurance under the VMI and MHI programs;

- to identify and analyze restrictions on the use of these indicators in the practice of pharmacies;

- to outline the peculiarities of the use of the results obtained and the directions of further research on the topic.

\section{Materials and methods}

In accordance with the identified objects, we have selected the following materials: data from the domestic regulatory framework that regulates the accounting and reporting system in entities of various forms of owner- 
ship, in particular in pharmacies and insurance companies, as well as special literature; legislative and regulatory acts that regulate the organization of insurance activities in Ukraine and the formation of financial stability of insurance companies conducting operations with HI. Particular attention was paid to the analysis of the list of indicators proposed in 2009, which are used in the analysis of the effectiveness of pharmacy insurance coverage of health facilities [7].

Given the fact that the studies were theoretical in nature, we chose such methods of scientific search and cognition as historical, systemic, logical, hypotheticaldeductive, mathematical-statistical, etc.

\section{Results of the research}

The objects of the study were the data of the legal framework regulating insurance activity in Ukraine, as well as the special literature covering the issues of organization of pharmacy establishments under the conditions of HI implementation. The studies used historical, comparative, logical, semantic, hypothetical-deductive, systemic and other methods of scientific research.

Based on the results of understanding the contemporary role of pharmacies and taking into account previously conducted research in the above direction, we have determined the following. Analysis of the effectiveness of pharmacy establishments under the conditions of $\mathrm{HI}$ implementation should be carried out in the following areas:

- offered programs for MHI, VMI, including micro-insurance products for health and temporary disability, as well as complementary HI;

- lists of drugs consumed under different programs of public service or the cost of which are included in insurance tariffs using different approaches, and compensation is made by different mechanisms. In addition, special attention should be paid to the list of drugs that are on the subject-quantitative account in pharmacies (drugs, precursors, psychotropic and poisonous drugs);

- population groups and categories of patients who had prescribed medicines or MD on insurance prescriptions;

- doctors who have prescribed insurance prescriptions for their specialty and place of work (public or private medical institutions and their administrative and territorial subordination);

- sources of compensation for medicines and MD from prescriptions (directly to the state budget, subsidies to local state budgets, local community budgets, MHI funds, insurance payments under VMI programs of insurance companies, charitable foundations or humanitarian contributions, citizens' funds, etc.).

In the modern system of pharmaceutical supply, pharmacies are considered not only as establishments that must be competitive and perform trade-production functions, and profit. Nowadays, the state and the community are increasingly paying attention to the involvement of pharmacy establishments of various forms of ownership and management in the implementation of socially important projects and programs, the implementation of which is not always linked to profit. Considering the current dualism in the organization of pharmaceutical supply to the population, we believe that the analysis of the insurance component in the activity of pharmacies should be carried out using all three accounting measures, namely cost (monetary, such as compensation for the value of medicines dispensed), natural (number of dispensed medicines, MD, patients, insured persons, etc.) and temporary (for example, pharmacy receivables for prescribed medicines and MD, etc.). In order to organize the effective management of the process of servicing the population under insurance prescriptions, the analysis of indicators characterizing the pharmacy insurance activity should be carried out in accordance with the following stages:

- preliminary (analysis of environmental factors that directly affect the effectiveness of pharmacy in the pharmaceutical market segment for servicing the population by insurance prescriptions, the choice of rational ways to improve the efficiency of processing the necessary statistical indicators, the introduction of modern software for automated information processing, etc.);

- organizational and administrative (automated collection of statistical data, which is conducted under a centralized procedure, control of the reliability of the input information, checking the effectiveness of feedback with other subjects of insurance relations in the system of pharmaceutical security of the population, etc.);

- estimated and effective (organization of internal accounting of indicators used in the analysis, calculation and automated processing of relevant indicators, their analysis in the short and medium term);

- management (formation of rational management decisions in the direction of increasing the efficiency of pharmacy establishments with insurers, state and non-state funds that compensate for the cost of medicines and MD consumption, increasing the competitiveness of the pharmacy in the relevant segment of the insurance and pharmaceutical market, and expanding the scope of activities pharmacy business social responsibility to the community).

In analyzing the performance of pharmacy establishments under insurance prescriptions, we propose to use two types of indicators. The first type includes absolute or relative indicators that characterize directly insurance formulas and are measured in natural or value accounting meters (Table 1). 
List and procedure of calculations of indicators used in the analysis of pharmacy insurance activity

(first type indicators)

\begin{tabular}{|l|}
\hline \multicolumn{1}{|c|}{ Indicator } \\
(units of measurement)
\end{tabular}

The total number of insurance prescriptions received at the pharmacy over
a period of time in all areas of analysis (forms of insurance, sources of
compensation for medicines or MD, population or sick, medicines, pre-
scribers, etc.) is calculated. Specialty assessment of the correctness of
prescription insurance is made using the methods of syntactic and seman-
tic control of the content of the recipes. With $100.0 \%$ connection of phar-
macies to E-Health, this control will be performed automatically at the
level of prescribing by doctors in medical institutions.

3 indicators in total

2. The proportion (\%) of insurance prescriptions in the total pharmacy prescription over a period of time, including separately in the total of prescriptions already received at the pharmacy and for which medicines or MD clients have already been released
Defined as the ratio of the number of insurance prescriptions to the total number of prescriptions that came to the pharmacy, or the number of prescriptions that have already been dispensed to medicines or MD clients over a period of time

\section{2 indicators in total}

3. Average value of medicines or MDs that have been issued for prescription over a period of time

It is calculated as the ratio of the actual value of medicines or MD on insurance prescriptions to their number over the relevant time period. The calculation, analysis and control of the indicator is carried out in such areas as forms of insurance, sources of compensation for the value of medicines or MD, population or sick, lists of medicines, prescribers, etc.).

\section{1 indicator in total}

It is determined by the results of the analysis of the sums of compensation of medicines or MD on insurance prescriptions. It is calculated as the ratio of the actual amount of compensation for the value of medicines or MDs dispensed to their amount over the relevant time period. The calculation, analysis and control of the indicator is carried out in all areas of analysis of insurance formulation (see above).

\section{1 indicator in total}

5. Average value of co-pay for a pharmacy customer in the total cost of dispensed medicines or MD for insurance prescriptions over a period of time
It is calculated as the ratio of the cost of dispensed medicines or MD under insurance prescriptions paid directly by the pharmacy client to their quantity over the relevant time period. The calculation, analysis and control of the indicator is carried out in all areas of analysis of insurance formulation (see above).

1 indicator in total

The total number of indicators of the first type -8 .

To the second type was attributed the indicators that characterize the effectiveness of the financial component in the organization of pharmacies in the insurance market under the VMI programs or in the model MHI, government programs, such as the program "Available Medicines" and more. Indicators of the second type can be presented in natural, value and time meters (Table 2). 
Indicators characterizing the socio-economic effectiveness of pharmacy activity as a subject of insurance activity in the pharmaceutical supply system (second type indicators)

\begin{tabular}{|l}
\multicolumn{1}{c}{$\begin{array}{c}\text { Indicator } \\
\text { (units of measurement) }\end{array}$} \\
\hline $\begin{array}{l}\text { 1. The full duration of the operating } \\
\text { cycle (number of hours or days) of an } \\
\text { insurance prescription, consisting of: }\end{array}$ \\
$\begin{array}{l}\text { 1.1. Duration of the first stage of the } \\
\text { operating cycle of the insurance pre- } \\
\text { scription; }\end{array}$
\end{tabular}

1.2. The duration of the second stage of the operating cycle of the insurance prescription

1.3. The duration of the third stage of the operating cycle of the insurance prescription

\section{Calculation procedure}

The total duration of the operating cycle is defined as the number of hours or days from the time when the doctor prescribes an insurance prescription to the patient or pharmacy client until the reimbursement of the value of the medicines or MD to the pharmacy account is received. It consists of three stages. The first stage of the cycle starts from the moment the doctor prescribes it to the pharmacy. At a time of $100.0 \%$ connection of pharmacies to "E-Health", the specified period will approach in time to "0". The second stage begins with the co-payment (cash or non-cash payment) to a patient or pharmacy client for the drug or MD actually dispensed. The third stage is deducted from the moment of receipt to the institution of an insurance prescription and to the time of receipt of the amount of compensation to the pharmacy's account from different sources of financing in the model MHI, VMI or under the programs of financing state programs. It is advisable to control not only the duration of all stages of the operating cycle of an insurance prescription, but also the number of insurance prescriptions that are in all three stages of promotion of insurance prescriptions.

\section{3 indicators in total}

Time averaged over the period from the drug or MD's release date and the cash flow to the pharmacy account (first accumulation level), as well as from the period of invoicing to the company or fund that reimburses the value of medicines or MD's insurance prescriptions before the date of cash withdrawal at pharmacy evaluated account (the second level of accumulation, which coincides with the end of the third stage of the operating cycle of the prescription).

\section{2 indicators in total}

2. Ratio of pharmacy insurance activity in different areas of insurance activity:

2.1. Prescription leave;

2.2. Total of pharmacy goods sold (retail, wholesale and general turnover)

2. The coefficient of insurance compensation for different areas of insurance activity:

2.1. Prescription dispense;

2.2. Total of pharmacy products sold (retail, wholesale and general turnover)

3. Profitability of insurance activity $(\%)$ : 3.1 Prescription dispense;

3.2. Total of pharmacy products (retail, wholesale and general turnover)

It is calculated as the ratio of the value of medicines or MDs dispensed by insurance prescriptions to the cost of all prescription drugs that have been released over a period of time from a pharmacy. In addition, the ratio of the value of insurance prescriptions to the retail, wholesale and general turnover of the pharmacy over a certain period of time is calculated.

4 indicators in total

It is calculated as the ratio of the indemnity of medicines or MDs granted under insurance prescriptions to the value of all prescription drugs that were released over a period of time from a pharmacy, as well as to prescriptions for the retail, wholesale, and general turnover of the pharmacy over a period of time.

\section{4 indicators in total}

It is calculated as the ratio of profits earned by a pharmacy for dispensing medicines or MD on insurance prescriptions to the actual cost of all prescription drugs that were released over a period of time from the pharmacy. In addition, the revenue from the sale of drugs and MD under insurance prescriptions refers to the retail, wholesale and general turnover of the pharmacy over a period of time.

4 indicators in total

4. Profitability of insurance activity (\%) by pharmacy expenses from main activity:

3.1. Prescription dispense;

3.2. Total of pharmacy products (retail, wholesale and general turnover)

It is calculated as the ratio of the profits earned by a pharmacy for medicines or MD, for insurance prescriptions to the cost of the pharmacy associated with the organization of prescription medication and VPM from the pharmacy, as well as the cost of retail, wholesale sale of products, and all principal activities in system of pharmaceutical supply to the population. 4 indicators in total

The total number of indicators of the second type -21 .

As we can see from the data in tab. 1-2 total of 8 indicators of the first and 21 indicators of the second type are offered, that means 29 indicators in total. 


\section{Discussion of results}

Despite the qualitative changes that have taken place in the system of pharmaceutical supply to the population over the last years in Ukraine, the indicators, which were proposed by scientists in 2009, are not losing their relevance and practical importance, namely:

- ratio of account receivables turnover $\left(\mathrm{R}_{\mathrm{ART}}\right)$;

- duration of account receivables turnover $\left(\mathrm{D}_{\mathrm{ART}}\right)$;

- balance of insurance activity $\left(\mathrm{B}_{\mathrm{IA}}\right)$, which is defined as the difference between the retail value of medi- cines and MDs dispensed under insurance prescriptions and the indemnity rate of medicines or MDs that have been sold by a pharmacy over a period of time;

- pharmacy insurance account receivables $-\mathrm{I}_{\mathrm{AR}}$ [7].

$\mathrm{A} \mathrm{B}_{\mathrm{IA}}$ value of $>0$ indicates that the pharmacy accounts receivable has been accumulated and necessitates prompt management decisions to eliminate negative trends. Ratio of account receivables turnover $\left(\mathrm{R}_{\mathrm{ART}}\right)$ and duration of account receivables turnover $\left(\mathrm{D}_{\mathrm{ART}}\right)$ are calculated using formulas used in financial analysis and adapted to the specifics of pharmacy establishments:

$$
R_{A R T}=\frac{\text { total pharmacy turnover over a period of time, hrn }}{\text { the average cost of net receivables over a period of time, hrn }},
$$

$$
D_{A R T}=\frac{\text { number of days in the period }}{R_{A R T}}[7] \text {, }
$$

The $\mathrm{I}_{\mathrm{AR}}$ indicates the status of accounts receivable from medicines and MD clients or patients with insurance prescriptions. This figure is calculated as the proportion (\%) of the value of dispensed medicines and MD from the total receivables of the pharmacy:

$$
I_{A R}=\frac{R V, h r n}{\sum A R} \times 100 \%[7],
$$

where $R V$ - retail value of dispensed medicines or MD at retail prices, hrn; $\sum_{A R}$ - total amount of accounts receivable of pharmacy establishments for a certain period of time, hrn.

Thus, taking into account the results of previous studies and our own data, we have proposed an updated system of indicators that characterizes the socioeconomic efficiency of pharmacy as an important subject of insurance relations in the health care system. We believe that the totality of the presented figures allow us to fully evaluate the effectiveness of the pharmacy, as an important subject of insurance activity in the market of medical and pharmaceutical services. Considering the dynamic nature of the development of the domestic insurance market and the permanent increase in the social responsibility requirements of pharmacies, it is understandable that the number of indicators will increase. This necessitates the need for a more active use of modern software and connection to modern health information retrieval systems when analyzing the effectiveness of pharmacy insurance activities. It is also important to emphasize the fact that in calculations that are measured in terms of value, data from medicines or MDs should be used exclusively at retail prices. Given the market need for pharmacy profits, the calculation of relevant indicators in purchase prices is pointless.

Another limitation of our research is due to the fact that the effective use of the results of the analysis of these indicators in the long term requires normalization, that is, determining the optimal interval of these data.

At the end of the studies, the following should be noted. An important area of further research will be to determine the normative values of various indicators, taking into account the specific activity of pharmacies in different forms of ownership and management in Ukraine.

The results of the research can be used to develop effective tariff policy in the domestic insurance market and to increase the level of competitiveness of pharmacies in the pharmaceutical market, provided that insurance relations are introduced into the national health care.

\section{Conclusions}

According to the results of the conducted researches, the main directions of conducting the analysis of the effectiveness of the activity of pharmacy establishments under the conditions of introduction of insurance relations in the national health care system and pharmaceutical supply of the population of Ukraine are substantiated.

Given the current dualism in the organization of pharmacy activities in the direction of providing affordable pharmaceutical assistance to the public in the conditions of introduction of insurance relations in health care, we believe that in the analysis of its insurance activity can be used all three accounting measures, namely natural, cost and time.

According to the results of our research, we have proposed organizational and economic approaches to the analysis of the insurance component in the activity of pharmacy establishments, which should be consistently implemented in four stages (preliminary, organizational-administrative, evaluated and effective, managerial). In total, we offered 29 indicators of analysis, which are divided into two types. The indicators of the first type ( 8 indicators) were those that characterized the pharmacy insurance prescription, and the second (21 indicators) - those that characterize the effectiveness of the financial component in the organization of activities of pharmacies in the insurance market under VMI programs or in the MHI model, government programs, and more.

The scientific novelty of the conducted research is the development of a set of indicators that, on the one hand, allow to evaluate the effectiveness of the economic component in the work of the pharmacy, and on the other - highlight the problematic issues of developing rational mod- 
els of relations in the health care system with insurance companies. Taking into account the realities of today, first of all, the social burden on pharmacies and the recent changes in national health care, such as the introduction of the E-Health elements or the government's program "Affordable Drugs", have been proposed, it also has practical implications. Thus, in our opinion, its use allows us to quickly determine and evaluate the level of efficiency of pharmacies in the conditions of introduction of insurance relations in different directions, including, for VMI programs.

\section{Conflict of interests}

There is no conflict of interest.

\section{References}

1. Dalton, K., Byrne, S. (2017). Role of the pharmacist in reducing healthcare costs: current insights. Integrated Pharmacy Research and Practice, 6, 37-46. doi: http://doi.org/10.2147/iprp.s108047

2. Tate, M. L., Hopper, S., Bergeron, S. P. (2018). Clinical and Economic Benefits of Pharmacist Involvement in a Community Hospital-Affiliated Patient-Centered Medical Home. Journal of Managed Care \& Specialty Pharmacy, 24 (2), 160-164. doi: http://doi.org/10.18553/jmcp.2018.24.2.160

3. Barlas, S. (2015). Insurance Companies Struggle to Balance Medical and Pharmacy Networks. Cost and Access Are Often at Odds; Enrollees Are Caught in the Middle. Pharmacy and Therapeutics, 40 (1), 41-43. $589-598$

4. Handfield, R., Feldstein, J. (2013). Insurance companies' perspectives on the orphan drug. Am Health Drug Benefits, 6 (9),

5. Danylchenko, L. (2017). The study of features and prospects of the insurance medicine in Ukraine in modern conditions. ScienceRise: Medical Science, 3 (11), 9-15. doi: http://doi.org/10.15587/2519-4798.2017.96222

6. Volokhova, L. F., Ostapenko, D. O. (2017). Medichne strakhuvannia ta iogo rozvitok v Ukraini. Finansovye uslugi, 1, 35 39. Available at: http://nbuv.gov.ua/UJRN/finu_2017_1_10

7. Panfilova, H. L. (2009). Rozrobka systemy pokaznykiv, shcho kharakteryzuiut strakhovu retseptury apteky. Visnyk farmatsii, 3 (59), 56-59.

8. Nemchenko, A. S., Panfilova, H. L., Korzh, Yu. V., Borozenets, N. I. (2010). Rozrobka efektyvnoi modeli finansovoho zabezpechennia vykonannia derzhavnykh tsilovykh prohram za umov vprovadzhennia oboviazkovoho medychnoho strakhuvannia. Zaporizkyi medychnyi zhurnal, 12 (2), 107-113.

9. Krychkovska, A. M., Komar, V. S., Novikov, V. P. (2012). Medychnyi klaster yak strukturna odynytsia systemy oboviazkovoho medychnoho strakhuvannia. Klinichna farmatsiia, farmakoterapiia ta medychna standartyzatsiia, 1-2, $139-142$.

10. Khodakivska, V. P., Kotvitska, A. A., Korobova, Ye. S., Pastukhova, O. A. (2012). Istorychni aspekty rozvytku medychnoho strakhuvannia v Ukraini. Zaporizkyi medychnyi zhurnal, 5, 116-119.

11. Bazylevych, V. D. et. al.; Bazylevych, V. D. (Ed.) (2008). Strakhuvannia. Kyiv: Znannia, 1019

12. Rubtsova, N. M., Chkan, I. O. (2015). Suchasnyi stan rynku medychnoho strakhuvannia v Ukraini: problemy ta perspektyvy rozvytku. Finansovyi prostir, 4 (20), 167-172.

13. Lisoval, V. P. (2009). Otsinka rezultativ diialnosti strakhovoi kompanii. Problemy systemnoho pidkhodu v ekonomitsi, 2 (10). Available at: http://jrnl.nau.edu.ua/index.php/EPSAE/article/viewFile/4419/4548

14. Voronina, O. O. (2015). Naukovi pidkhody do vyznachennia sutnosti medychnoho strakhuvannia. Naukovyi visnyk Mykolaivskoho natsionalnoho universytetu imeni V. O. Sukhomlynskoho, 8, 733-737.

15. Muzyka, O. M. (2017). Stan ta tendentsii rozvytku strakhovoho rynku Ukrainy. Zbirnyk naukovo-tekhnichnykh prats NLUU, 246-255.

16. Mishchuk, I., Vinnichuk, I. (2019). Suchasnyi stan oboviazkovoho medychnoho strakhuvannia v Ukraini ta shliakhy yoho rozvytku. Pidpryiemstvo, hospodarstvo i pravo, 2, 110-114.

17. Fedorova, N. O. (2018). Medychne strakhuvannia v systemi derzhavnoho rehuliuvannia strakhovoi diialnosti. Available at: http://repositsc.nuczu.edu.ua/bitstream/123456789/6952/1/27\%20.pdf

Рекомендовано до публікації д-р фарм. наук, професор Косяченком К. Л.

Received date 30.07.2019

Accepted date 20.08.2019

Published date 31.08.2019

Hanna Panfilova, Doctor of Pharmaceutical Sciences, Professor, Department of Organization and Economics of Pharmacy, National Pharmaceutical University, Pushkinska str., 53, Kharkiv, Ukraine, 61002

E-mail: panf-al@ukr.net

Liliia Hala, PhD, Associate Professor, Department of Organization and Economics of Pharmacy, Bogomolets National Medical University, T. Shevchenko blvd., 13, Kyiv, Ukraine, 01601

E-mail: hala.liliia@gmail.com 